\title{
Cytokine-Induced Activation of Signal Transducer and Activator of Transcription in Photoreceptor Precursors Regulates Rod Differentiation in the Developing Mouse Retina
}

\author{
Kun Do Rhee, ${ }^{1}$ Olivier Goureau, ${ }^{1}$ Shiming Chen, ${ }^{2}$ and Xian-Jie Yang ${ }^{1}$ \\ ${ }^{1}$ Department of Ophthalmology, Jules Stein Eye Institute, David Geffen School of Medicine, Molecular Biology Institute, University of California, Los \\ Angeles, California 90095, and ${ }^{2}$ Departments of Ophthalmology and Vision Sciences and Molecular Biology and Pharmacology, Washington University \\ School of Medicine in St. Louis, St. Louis, Missouri 63110
}

\begin{abstract}
Ciliary neurotrophic factor (CNTF) exhibits multiple biological effects during vertebrate retinogenesis, including regulation of photoreceptor cell differentiation. In the early postnatal mouse retina, CNTF induces rapid and transient phosphorylation of signal transducer and activator of transcription (STAT) 1 and STAT3 and the extracellular signal-regulated kinase (ERK). Although both proliferating progenitor cells and postmitotic neurons respond directly to cytokine signals, CNTF elicits distinct phosphorylation patterns of STAT3 and ERK. CNTF stimulation induces low levels of STAT3 phosphorylation in progenitors and differentiated neurons but a robust STAT3 activation among postmitotic photoreceptor precursors expressing the cone-rod homeobox gene Crx and newly differentiated rod photoreceptors. In contrast, CNTF causes preferential phosphorylation of ERK in progenitor cells and photoreceptor precursors. Inhibition of the cytokine receptor gp 130 using neutralizing antibodies reveals that gp130 is required for both CNTF-induced STAT3 and ERK phosphorylation. Perturbation of STAT signaling by a STAT inhibitor peptide or a dominant-negative STAT3 mutant causes enhanced production of rod photoreceptors in the absence of exogenous cytokines, whereas inhibiting ERK activation by a MEK (mitogen-activated protein kinase kinase)-specific inhibitor has no effect on rod photoreceptor differentiation in vitro. Furthermore, disrupting the function of epidermal growth factor (EGF) receptors, which modulate rod development in vivo, indicates that the EGF family of ligands does not mediate the inhibitory effect of cytokine on rod differentiation. These results demonstrate that cytokine signal transduction is dynamic and heterogeneous in the developing retina, and that endogenous ligand-induced STAT activation in retinal progenitor and/or photoreceptor precursor cells plays an important role in regulating photoreceptor development.
\end{abstract}

Key words: CNTF; retina; differentiation; STAT; ERK; photoreceptor

\section{Introduction}

The vertebrate retina contains seven major neuronal cell types that are derived from multipotent progenitor cells (Turner and Cepko, 1987; Holt et al., 1988; Wetts and Fraser, 1988; Turner et al., 1990). Accumulating evidence suggests that retinal cell fate specification and differentiation are regulated by both cellintrinsic and cell-extrinsic mechanisms (Cepko et al., 1996; Lil-

Received May 9, 2004; revised Sept. 17, 2004; accepted Sept. 18, 2004.

This work is supported by grants from the Research to Prevent Blindness Foundation, March of Dimes Birth Defects Foundation, Karl Kirchgessner Foundation, and National Eye Institute (EY12270, EY01444) to X.-J.Y. S.C. is supported by Research to Prevent Blindness and the National Eye Institute (EY12543). 0.G. was supported in part by Institut National de la Santé et de la Recherche Médicale (France) and a North Atlantic Treaty Organization Travel Fellowship. K.D.R. is supported by National Eye Institute training Grant T32 EY07026. We thank Ke Shuai and Robert Molday for gifts of antibodies.

Correspondence should be addressed to Xian-Jie Yang, Jules Stein Eye Institute, University of California Los Angeles School of Medicine, 100 Stein Plaza, Los Angeles, CA 90095. E-mail: yang@jsei.ucla.edu.

0. Goureau's present address: Laboratoire de Physiopathologie Cellulaire et Moléculaire de la Rétine, Institut National de la Santé et de la Recherche Médicale U592, Hôpital Saint-Antoine, 75571 Paris cedex 12, France.

DOI:10.1523/JNEUROSCI.1785-04.2004

Copyright $\odot 2004$ Society for Neuroscience $\quad$ 0270-6474/04/249779-10\$15.00/0 lien, 1998; Livesey and Cepko, 2001; Cayouette et al., 2003; Yang, 2004). Among cell-extrinsic cues, the ciliary neurotrophic factor (CNTF) family of cytokines strongly affects retinogenesis, especially the development of photoreceptor cells. In rodents, CNTF inhibits rod photoreceptor differentiation as indicated by the suppression of rhodopsin expression (Ezzeddine et al., 1997; Neophytou et al., 1997; Schulz-Key et al. 2002). This inhibitory effect on rod differentiation is accompanied by an increase of bipolar cell marker expression in the rat retina (Ezzeddine et al., 1997; Bhattacharya et al., 2004). In contrast to rodents, CNTF promotes the differentiation of a subclass of cone photoreceptors in the developing chicken retina (Fuhrmann et al., 1995; Kirsch et al., 1996; Xie and Adler, 2000).

The CNTF family of cytokines signals through the transmembrane cytokine $\beta$ receptors gp130 and leukemia inhibitory factor receptor $\beta$ (LIFR $\beta)$ and often an additional ligand-specific $\alpha$ receptor (Davis et al., 1993; Ip et al., 1993). Ligand binding results in the activation of the Jak (Janus kinase) tyrosine kinases, which phosphorylate the $\beta$ receptors and two members of the signal transducer and activator of transcription (STAT) family, STAT1 
and STAT3 (Stahl and Yancopoulos, 1994; Rajan et al., 1996; Heinrich et al., 1998). The tyrosine-phosphorylated forms of STAT dimerize and translocate into the nucleus to regulate gene transcription (Bonni et al., 1993). In addition to the Jak-STAT signaling pathway, the CNTF family of cytokines can also activate the extracellular signal-regulated kinase (ERK) (Boulton et al., 1994) and the phosphatidylinositol 3 kinase-Akt pathway (Oh et al., 1998).

Existing evidence indicates that CNTF can influence rod photoreceptor differentiation after progenitor cells exit from the cell cycle but before the onset of rhodopsin expression (Ezzeddine et al., 1997; Schulz-Key et al., 2002). However, because the distribution of cytokine signaling components in the retina suggests that both progenitor cells and postmitotic neurons may respond to cytokines (Rhee and Yang, 2003; Zhang et al., 2003), it remains unclear whether CNTF acts directly on photoreceptor precursors or signals indirectly through other cell types to influence photoreceptor differentiation. We have analyzed the target cell types and signaling events for CNTF in the developing retina. Our results show that cytokine receptors mediate heterogeneous activation of STAT and ERK among various cell types, and that postmitotic photoreceptor precursors directly respond to cytokine signals. In addition to CNTF, signals mediated by epidermal growth factor receptors (EGFRs) have also been shown to suppress rod photoreceptor development in rodents (Lillien, 1995; Neophytou et al., 1997). We show that inhibition of rod differentiation by cytokines is not caused by the secondary release of epidermal growth factor (EGF) family ligands. Moreover, we demonstrate that activation of STAT instead of ERK is involved in regulating rod photoreceptor differentiation during the critical developmental period.

\section{Materials and Methods}

Animals, growth factors, inhibitors, and antibodies. Retinal tissues were derived from CD1 mice obtained from Charles River (Wilmington, MA). Recombinant rat CNTF and murine EGF were purchased from PeproTech (Rocky Hill, NJ). Recombinant human leukemia inhibitory factor (LIF) and brain-derived neurotrophic factor (BDNF) were obtained from R\&D Systems (Minneapolis, MN). The MEK (mitogen-activated protein kinase kinase)1/MEK2-specific inhibitor 1,4-diamino-2,3dicyano-1,4-bis(2-aminophenylthio)butadiene (U0126) was purchased from Cell Signaling Inc. (Beverly, MA). The phosphotyrosyl peptide STAT inhibitor and the EGFR inhibitor 4-(3-chloroanilino)-6,7dimethoxyquinazoline (AG1478) were purchased from Calbiochem (La Jolla, CA). Sources and dilutions of antibodies used in this study are summarized in the supplemental material (available at www.jneurosci.org).

Dissociated cell cultures. Dissected postnatal retinas were dissociated with trypsin, as described previously (Altshuler and Cepko, 1992). For Western blot analyses, cells were plated in $60 \mathrm{~mm}$ culture dishes coated with poly-D-lysine $\left(2 \mu \mathrm{g} / \mathrm{cm}^{2}\right)$ and incubated in the base neural medium [DMEM/F12 (1:1) with 10 mM HEPES, pH 7.0] containing N2 supplement (Invitrogen, San Diego, CA) at $37^{\circ} \mathrm{C}$ in $5 \% \mathrm{CO}_{2}$ for $5 \mathrm{hr}$ before treatment with growth factors. For immunostaining of phosphoproteins, dissociated retinal cells were plated for $4 \mathrm{hr}$ at $10,000 \mathrm{cells} / \mathrm{mm}^{2}$ in the base neural medium containing N2 on eight-well LabTech slides (Nalge Nunc International, Naperville, IL) coated with poly-D-lysine (10 $\mu \mathrm{g} / \mathrm{ml}$ ) before treating with $100 \mathrm{ng} / \mathrm{ml}$ CNTF for $10 \mathrm{~min}$.

Retinal explant cultures. Postnatal mouse retinal explants were placed on top of polycarbonate filter discs (Millipore, Bedford, MA) and cultured in the base neural medium containing N2, as described previously (Ezzeddine et al., 1997). After a specified number of days in vitro, explants were dissociated with trypsin (Altshuler and Cepko, 1992). Cell suspensions were plated on glass slides coated with poly-D-lysine and allowed to attach at $37^{\circ} \mathrm{C}$ in $5 \% \mathrm{CO}_{2}$ for $1-2 \mathrm{hr}$ before fixation and immunostaining (Ezzeddine et al., 1997; Zhang and Yang, 2001).

To assay STAT3 and ERK activation by immunostaining, whole retinal explants from different postnatal ages were placed with the ganglion cell layer up on Culture Plate Inserts (Millipore) and cultured in $1.5 \mathrm{ml}$ of the base neural medium containing N2. After $3 \mathrm{hr}$ of incubation at $37^{\circ} \mathrm{C}$, explants were treated with or without $100 \mathrm{ng} / \mathrm{ml} \mathrm{CNTF}$ for $15 \mathrm{~min}$ before fixation. Bromodeoxyuridine (BrdU) labeling of postnatal day 0 (P0) retinas was performed by injecting newborn mice intraperitoneally with $0.1 \mathrm{ml}$ of BrdU at $10 \mathrm{mg} / \mathrm{ml}$ and dissecting the retinas $13 \mathrm{hr}$ post injection.

Electroporation of retinal explants. To transfect retinal explants, dissected retinal cups were submerged in $1 \mu \mathrm{g} / \mathrm{ml}$ DNA in PBS and subjected to five electric pulses at $8 \mathrm{~V}$ with $10 \mathrm{msec}$ duration and $950 \mathrm{msec}$ intervals using a BTX (San Diego, CA) ECM830 square wave generator and paddle-type electrodes. The STAT3EE (Horvath et al., 1995) mutant cDNA was expressed from a murine leukemia virus long terminal repeat promoter, and the parental vector LIA (Bao and Cepko, 1997) was used as a control. Both STAT3EE and the control LIA vector were coelectroporated with a DNA construct that expresses enhanced green fluorescent protein from the chicken $\beta$-actin promoter (Matsuda and Cepko, 2004). Transfected explants were further cultured in vitro, as described above.

Western blot analysis. Retinal cell lysates were extracted from dissociated cell cultures by incubation in lysis buffer ( $50 \mathrm{~mm}$ Tris- $\mathrm{HCl}, \mathrm{pH} 7.8$, $250 \mathrm{~mm} \mathrm{NaCl}, 0.5 \% \mathrm{NP} 40$ ) containing $1 \mathrm{~mm}$ of orthovanadate and protease inhibitors, followed by centrifugation for $5 \mathrm{~min}$ at $5000 \mathrm{~g}$. The supernatants $(20 \mu \mathrm{g})$ were subjected to SDS-PAGE and electroblotting to nitrocellulose membrane (Millipore). After blocking the membranes in TBS (20 mм Tris- $\mathrm{HCl}, \mathrm{pH} 7.6,150 \mathrm{~mm} \mathrm{NaCl}$ ) containing 5\% skim milk, primary and secondary antibody incubations were performed in the blocking solution with extensive washes in between using TBS containing $0.1 \%$ Tween 20 . Signals of horseradish peroxidase conjugated to the secondary antibodies were detected using the Enhanced Chemiluminescence System (Amersham Biosciences, Piscataway, NJ).

Immunostaining and data analyses. Monolayer cell cultures on slides were fixed with $4 \%$ paraformaldelhyde in PBS for 15-20 min. Retinal explants were fixed overnight with $4 \%$ paraformaldelhyde in PBS at $4^{\circ} \mathrm{C}$ followed by cryoprotection in PBS containing 30\% sucrose. Tissues were embedded in Tissue-Tek OCT (Miles, Elkhart, IN), and $16 \mu \mathrm{m}$ sections were cut with a cryostat. After washes with PBS, nonspecific binding sites were blocked with DMEM containing 10\% FCS, $2 \%$ goat serum, $2 \%$ donkey serum, and $0.1 \%$ Triton X-100 for $1 \mathrm{hr}$ at room temperature or overnight at $4^{\circ} \mathrm{C}$. For double staining with anti-phospho-STAT3 and anti-phospho-ERK, cryosections or cells were washed three times with PBS and then incubated in deionized 95\% formamide-1.5\% $20 \times$ SSC, $\mathrm{pH} 7.0$, for $10 \mathrm{~min}$ at $70^{\circ} \mathrm{C}$. After formamide treatment, sections or cells were washed twice with PBS containing $0.1 \%$ Tween 20 (PBT) for $10 \mathrm{~min}$ at $4^{\circ} \mathrm{C}$ before binding with the primary antibodies. Primary antibodies (see supplemental material, available at www.jneurosci.org) were diluted in blocking solution and incubated with cells or sections at room temperature for $1 \mathrm{hr}$ or at $4^{\circ} \mathrm{C}$ overnight. After extensive washes with PBT, cells or sections were then incubated for $1 \mathrm{hr}$ at room temperature with appropriate secondary antibodies (supplemental material, available at www.jneurosci.org). Slides were washed extensively in PBT and during the last wash, treated for $5 \mathrm{~min}$ with $1 \mu \mathrm{g} / \mathrm{ml} \mathrm{4}$ '-6-diamidino-2phenylindole. Slides were mounted with Gel Mount (Biomeda, Foster City, CA). Fluorescent staining signals of monolayer cells were captured with a Nikon (Tokyo, Japan) E800 microscope equipped with a SPOT II digital camera. Confocal imaging was performed using Leica (Nussloch, Germany) TCS-SP or Zeiss (Oberkochen, Germany) Renaissance 410 confocal laser scanning microscopes as 1 or $2 \mu \mathrm{m}$ optical sections.

ImagePro Plus software (Media Cybernetics, Silver Spring, MD) was used to measure and analyze the intensity of fluorescent staining signals in dissociated cell cultures. The same cutoff thresholds for fluorescent staining signals were used for a given antibody combination and experiment. Quantification of marker staining is expressed as mean \pm SEM after statistical analysis using the Mann-Whitney $U$ test or Student's $t$ test. Probability values $<0.05$ were considered significant. A minimal of three independent experiments $(n=3)$ with a total of six separate fields $(640 \pm 18$ cells per field) of each condition was quantified. 
A
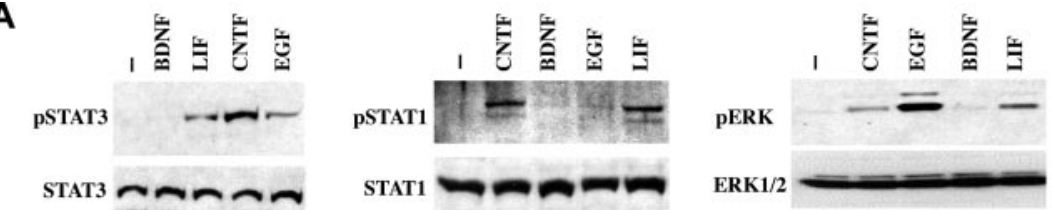

B

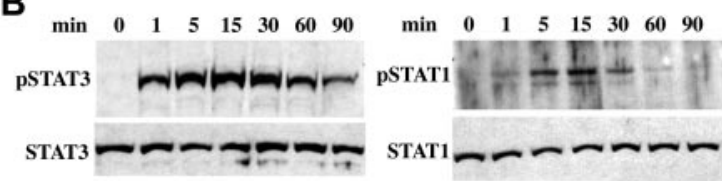

$\begin{array}{llllllll}\min & 0 & 1 & 5 & 15 & 30 & 60 & 90\end{array}$

C
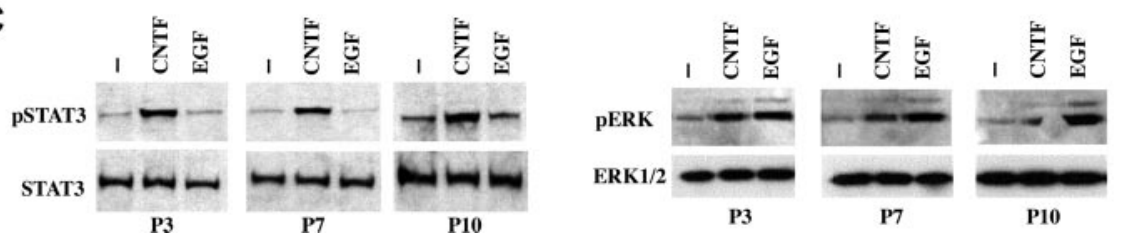

Figure 1. Signaling pathways activated by CNTF in the mouse retina. Western blots of STAT and ERK proteins as results of growth factor stimulations are shown. A, Phosphorylation of STAT1, STAT3, and ERK in dissociated P0 mouse retinal cells treated with BDNF, LIF, CNTF, or EGF (all at $10 \mathrm{ng} / \mathrm{ml}$ ) for $15 \mathrm{~min}$. The top panels were probed with anti-phospho-STAT1 (pSTAT1), phospho-STAT3 (pSTAT3), or phospho-ERK (pERK) antibodies. The bottom panels show the levels of total STAT1, STAT3, or ERK1/2 in the same cell extracts, respectively. $B$, Time courses of phosphorylation for STAT1, STAT3, and ERK in dissociated P0 mouse retinal cells after incubation with CNTF $(10 \mathrm{ng} / \mathrm{ml})$. The levels of total STAT1, STAT3, and ERK proteins are shown in the bottom panels. C, Phosphorylation of STAT3 or ERK in dissociated P3, P7, and P10 retinal cell cultures after 15 min stimulation with CNTF $(10 \mathrm{ng} / \mathrm{ml})$ or EGF $(10 \mathrm{ng} / \mathrm{ml})$. The bottom panels show total STAT3 or ERK proteins in the same extracts. Western blots shown represent one of three independent trials, which gave similar results. lated cells (Fig. 1A). In contrast, BDNF failed to cause a detectable increase of phospho-ERK, whereas stimulation with EGF resulted in a higher level of ERK phosphorylation than that induced by CNTF or LIF treatment (Fig. 1A). CNTFinduced ERK phosphorylation showed a rapid and transient time course in $\mathrm{P} 0$ retinal cells, mimicking that of CNTFinduced STAT activation, with a detectable signal at $1 \mathrm{~min}$ and peak levels of phosphorylation at $15 \mathrm{~min}$ followed by a rapid decline (Fig. $1 B$ ).

To determine whether a similar pattern of STAT3 and ERK phosphorylation occurred at different postnatal stages, we analyzed cell extracts from P3, P7, and P10 retinal cell cultures. Western blots detected increased phosphorylation of both STAT3 and ERK after CNTF treatment for all stages examined (Fig. 1C), demonstrating that CNTF was able to activate both STAT3 and ERK throughout early postnatal stages of retinal differentiation. In contrast, EGF-induced phosphorylation of ERK but not STAT3 was detected at the three postnatal stages analyzed (Fig. 1C).

\section{Results}

Activation of STAT and ERK by CNTF in the mouse retina

To elucidate signaling events triggered by CNTF in the postnatal retina, we examined the activation of STAT1 and STAT3 in primary retinal cell cultures using Western blots and antibodies specifically recognizing the tyrosine-phosphorylated forms of the two transcription factors. In dissociated P0 retinal cells, phospho-STAT1 and phospho-STAT3 were detected after a 15 min treatment with a saturating concentration of CNTF (10 ng/ $\mathrm{ml}$ ) but not after exposure to BDNF or in unstimulated cells (Fig. $1 A$ ). Treatment with $10 \mathrm{ng} / \mathrm{ml}$ of LIF, a CNTF related cytokine, similarly induced STAT1 and STAT3 phosphorylation (Fig. 1A). In contrast, EGF treatment $(10 \mathrm{ng} / \mathrm{ml})$ induced moderate STAT3, but not STAT1, phosphorylation (Fig. $1 \mathrm{~A}$ ).

The onset and duration of STAT1 and STAT3 activation were analyzed by sampling retinal cell extracts at various times after CNTF addition (Fig. $1 B$ ). Western blots detected STAT3 phosphorylation within $1 \mathrm{~min}$ after the addition of CNTF, with peak signals at $\sim 15 \mathrm{~min}$. However, cellular levels of phospho-STAT3 declined significantly from their maximal level by $90 \mathrm{~min}$ after CNTF addition, whereas the levels of total STAT3 protein remained constant during the entire period. A similar temporal profile of STAT1 phosphorylation was observed after CNTF treatment (Fig. 1B). Thus, CNTF-triggered STAT phosphorylation in the neonatal retina was rapid and transient.

The ras-ERK pathway, one of the mitogen-activated protein kinase (MAPK) pathways, represents a distinct signaling cascade that is activated in the adult retina after intravitreal injection of CNTF or its analog (Peterson et al., 2000; Wahlin et al., 2000). To determine whether CNTF activates the ERK pathway in the developing retina, specific antibodies that recognize the phosphorylated forms of ERK1 and ERK2 (p42/44 MAPK) were used in Western blot analysis. After CNTF or LIF treatment, an increased phosphorylation of ERK was observed compared with unstimu-

\section{Target cell types for CNTF in the neonatal retina}

To examine whether the Jak-STAT and the ERK pathways were activated in the same cells, we performed confocal microscopy of P0 retina coimmunostained for phospho-STAT3 and phosphoERK (Fig. 2). In the absence of exogenous CNTF, phosphoSTAT3 protein was mainly distributed in the inner retina, where differentiated ganglion cells and developing amacrine cells reside at this developmental stage (Fig. 2A). Very weak signals of phospho-ERK were detected in untreated P0 retina (Fig. 2C). After a $15 \mathrm{~min}$ treatment with $100 \mathrm{ng} / \mathrm{ml} \mathrm{CNTF}$, robust phosphoSTAT3 staining signals were observed in a subset of cells near the ventricular surface as well as in cells located in the inner retina (Fig. $2 \mathrm{~B}$ ). In addition, a relatively weak yet detectable increase of phospho-STAT3 staining signals was observed throughout the ventricular zone (Fig. $2 \mathrm{~B}$ ). CNTF treatment also resulted in an elevation of phospho-ERK staining signals in the ventricular zone (Fig. 2D). However, the phospho-STAT3 signals, which were nuclear, did not overlap significantly with the phospho-ERK staining signals in the confocal images (Fig. $2 F$ ).

To identify distinct retinal cell types responsive to CNTF stimulation, we analyzed retinal explants costained for phosphorylated signaling molecules and retinal cell-type markers using confocal microscopy (Fig. 3). In the absence of exogenous ligand, a subset of differentiated ganglion cells that express the POUdomain transcription factor Brn3a (Liu et al., 2000) contained phospho-STAT3 (Fig. 3A). In addition, a small subset of postmitotic amacrine cells that express a member of the retinoic acidresponsive gene activator protein- $2 \alpha$ (AP- $2 \alpha$ ) (West-Mays et al., 1999) also contained low levels of phospho-STAT3 (Fig. 3C). Among progenitor cells marked by the proliferating cell nuclear antigen (PCNA), very few cells costained with phospho-STAT3 (Fig. 3E). After 10 min of CNTF stimulation, the staining intensity of phospho-STAT3 in Brn3a ${ }^{+}$ganglion cells was enhanced (Fig. 3B); however, only a slight increase of phospho-STAT3 
staining was detected in $\mathrm{AP}-2 \alpha^{+}$amacrine cells (Fig. 3D). CNTF treatment also resulted in a low level of phospho-STAT3 throughout the ventricular zone that showed positive staining for PCNA (Figs. $2 B, 3 B, F)$, suggesting CNTF-induced STAT3 activation in the mitotic progenitor cell population. This result was further confirmed by costaining of phosphoSTAT3 and the progenitor cell marker BrdU (data not shown). Strikingly, the ventricular surface cells containing high levels of phospho-STAT3 did not colabel with PCNA (Fig. $3 F$ ), indicating that these cells were postmitotic.

We also examined the distribution of CNTF-induced phospho-ERK among different retinal cell types at $\mathrm{P} 0$. As detected by confocal imaging, CNTF treatment did not cause a significant increase of phospho-ERK staining signals among

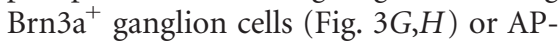
$2 \alpha^{+}$amacrine cells (Fig. $3 I, J$ ). In contrast, many $\mathrm{BrdU}^{+}$cells within the ventricular zone contained intense phospho-ERK staining signals (Fig. $3 \mathrm{~K}, \mathrm{~L}$ ). Similarly, costaining of phosphoERK and PCNA was also observed (data not shown), indicating that CNTF signals effectively increased ERK phosphorylation in progenitor cells.

These results demonstrate that both postmitotic neurons and proliferating progenitor cells in the neonatal mouse retina are responsive to CNTF signals. Furthermore, the intracellular signaling events triggered by CNTF are heterogeneous among progenitor cells and differentiated neurons.

\section{CNTF acts directly upon Crx-positive photoreceptor} precursor cells and nascent rod photoreceptors

Because the ventricular zone cells containing high levels of CNTF-induced phospho-STAT3 were not colabeled with the progenitor cell markers PCNA and BrdU, we next determined whether these cells were postmitotic photoreceptor precursors. Previous studies have shown that transcripts of the homeobox gene Crx are expressed by precursors of both rod and cone photoreceptors before the onset of opsin expression (Chen et al., 1997; Furukawa et al., 1997). We performed immunostaining using an anti-Crx antibody (La Spada et al., 2001) to determine the expression pattern of Crx protein in the developing retina. In the $\mathrm{P} 1$ retina, double immunostaining showed that $\mathrm{Crx}^{+}$cells were dispersed in the outer ventricular zone in between the PCNA $^{+}$progenitor cells (Fig. 4A). At P3, increasing numbers of cells near the ventricular surface stained positive for Crx (Fig. $4 B$ ). However, the majority of the $\mathrm{Crx}^{+}$cells did not contain PCNA. By P5, the $\mathrm{Crx}^{+}$and $\mathrm{PCNA}^{+}$cells were located in mutually exclusive zones of the retina (Fig. $4 C$ ). We also observed that between P1 and P5, a few $\mathrm{Crx}^{+}$cells showed low levels of PCNA within the proliferative zone (Fig. $4 A-C$ ). These data suggested that the onset of Crx protein expression coincided with the withdrawal of progenitor cells from the cell cycle. CNTF treatment of $\mathrm{P} 1$ retinas caused increased ventricular surface phospho-STAT3 staining, which colocalized with Crx staining signals (Fig. 4D, G). In addition, at both $\mathrm{P} 3$ and $\mathrm{P} 5$, a subset of $\mathrm{Crx}^{+}$cells in the outer ventricular zone showed intense costaining of Crx and phosphoSTAT3 in response to CNTF (Fig. 4E, H,F,I). These results dem- onstrate that postmitotic photoreceptor precursor cells directly respond to cytokine signals by activating STAT3.

We next examined whether differentiating photoreceptor cells could respond to CNTF signals. At P1, a small subset of cells located near the ventricular surface began to express rhodopsin as detected by anti-rhodopsin (Rho) antibody immunostaining (Fig. 4J) (Laird and Molday, 1988). After stimulation with CNTF, a subset of the Rho ${ }^{+}$cells showed costaining of phospho-STAT3 (Fig. $4 \mathrm{M}$ ), suggesting that newly differentiating rod photoreceptor cells were responsive to CNTF signals. Similarly, $\mathrm{Rho}^{+}$cells in the $\mathrm{P} 3$ retina showed elevated levels of phospho-STAT3 after exposure to CNTF compared with the control retina (Fig. $4 \mathrm{~K}, \mathrm{~N}$ ). By P5, phospho-STAT3 was detected only in $\mathrm{Rho}^{+}$cells localized in the outer portion of the nascent outer nuclear layer (Fig. $4 L, O)$. Because these cells have withdrawn from the cell cycle more recently than cells located in the deeper portion of the outer nuclear layer (Young, 1985), this result indicates that newborn photoreceptor cells lose their responsiveness to CNTF as differentiation proceeds. We also examined whether the ERK pathway is activated in photoreceptor precursors and/or differentiating rod cells. At P1, CNTF-induced phospho-ERK was distributed in the ventricular zone, and some $\mathrm{Crx}^{+}$and $\mathrm{Rho}^{+}$cells near the ventricular surface showed costaining with phospho-ERK (data not shown).

Together, these results demonstrate that postmitotic $\mathrm{Crx}^{+}$ photoreceptor precursors and nascent rod photoreceptor cells in the early postnatal retina are directly responsive to CNTF signals. Furthermore, both the Jak-STAT and the ERK pathways are activated in postmitotic photoreceptor precursors and in newly differentiating rod photoreceptors.

\section{Differential activation of STAT3 and ERK by CNTF among retinal cell types}

To characterize more precisely cytokine signaling events in the developing retina, we quantitatively analyzed the immunostaining of freshly dissociated P0 monolayer cultures. Consistent with the results obtained from confocal imaging of retinal explants, a 

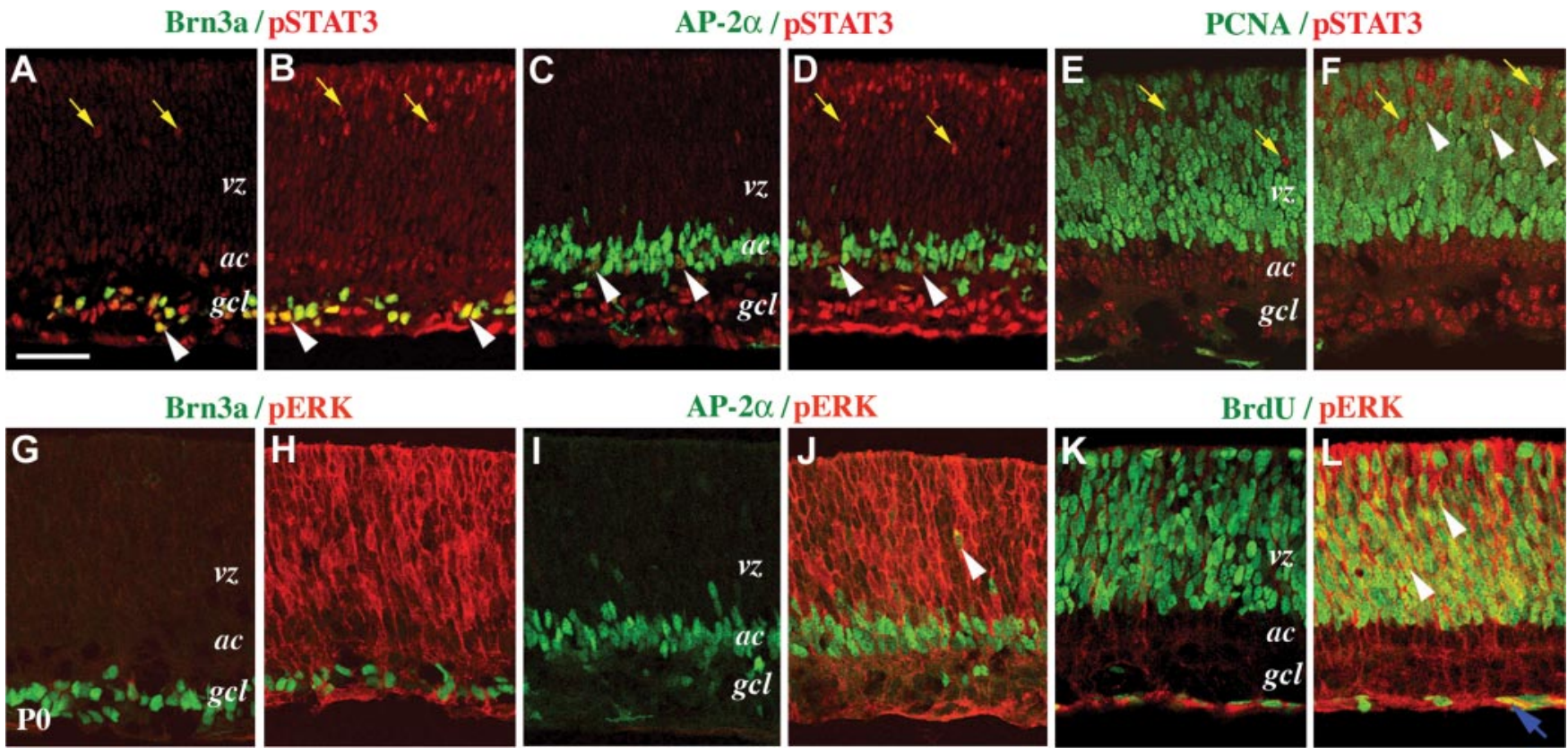

Figure 3. Target cell types for CNTF in the newborn mouse retina. Confocal microscopy images of immunostained P0 mouse retinal explants treated without $(A, C, E, G, I, K)$ or with $(B, D, F, H, J$, L) CNTF (100 ng/ml) for $15 \mathrm{~min}$ are shown. All panels represent merged optical sections (1 or $2 \mu \mathrm{m}$ ) stained with anti-phospho-STAT3 or anti-phospho-ERK (pSTAT3 or pERK; red) and cell type markers (green). White arrowheads indicate cells stained positive for both antibodies. Yellow arrows indicate pSTAT3 ${ }^{+}$cells not colabeled with cell type markers. The blue arrow $(L)$ points to the hyaloid blood vessels stained positive for BrdU and phospho-ERK. Scale bar: (in A) A-L, $50 \mu \mathrm{m}$. ac, Amacrine cells; gcl, ganglion cell layer; vz, ventricular zone.

PCNA / Crx
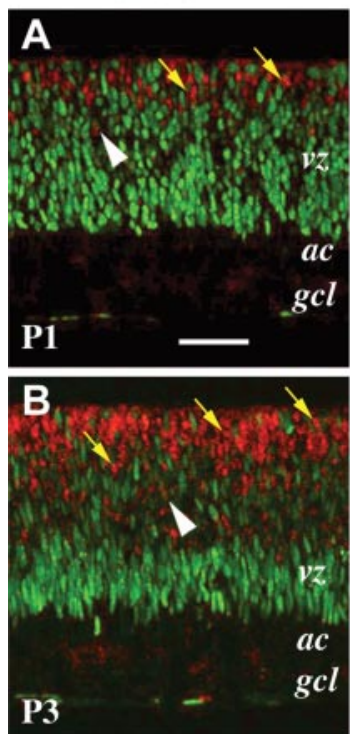

P5

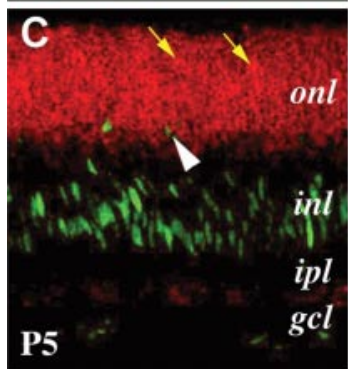

Crx / pSTAT3

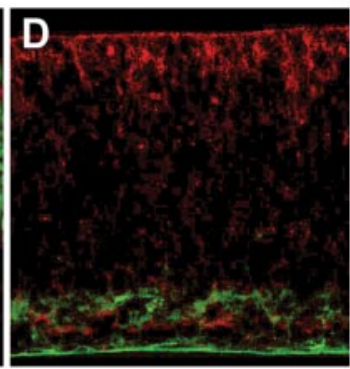

E
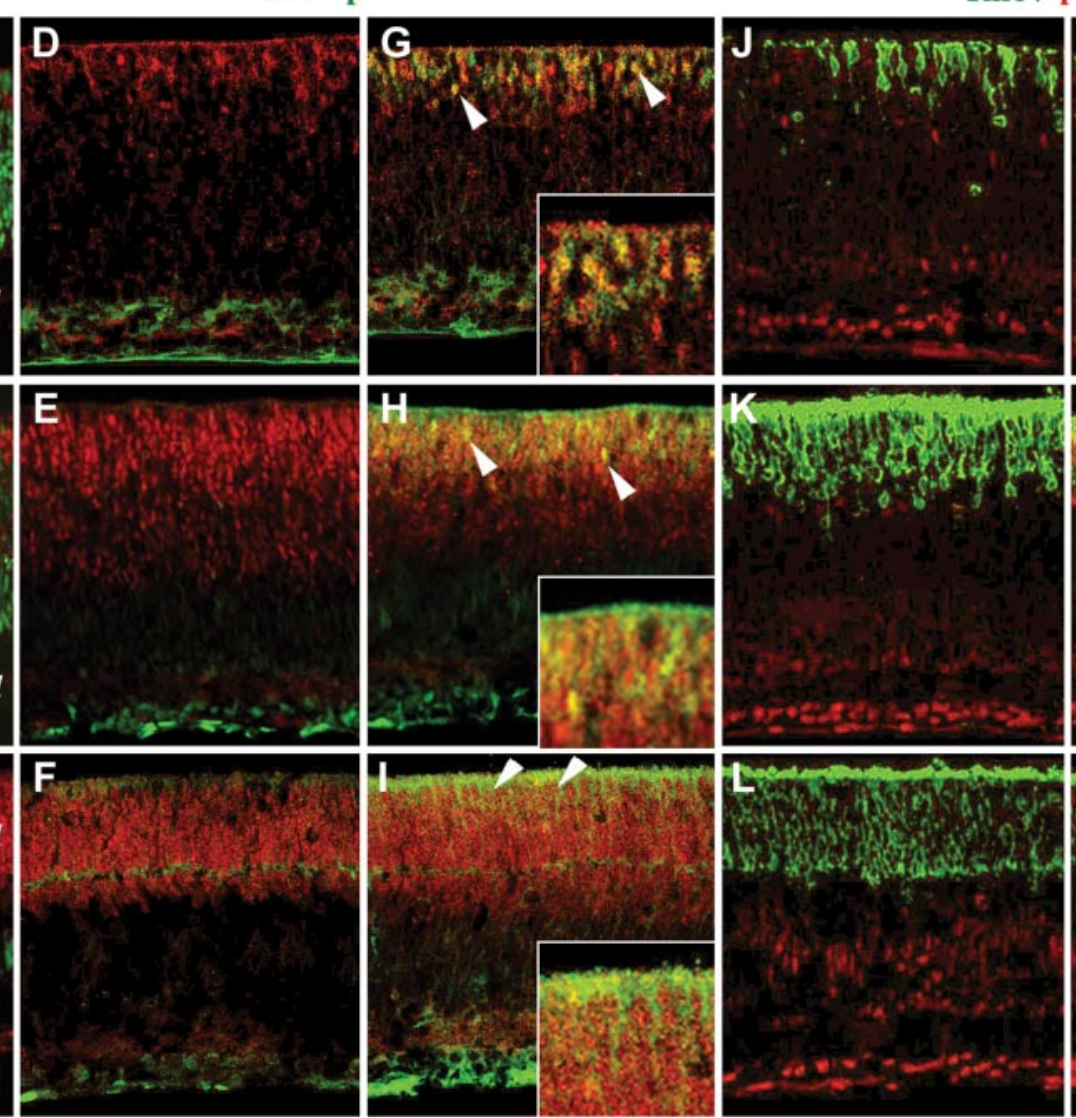

Rho / pSTAT3
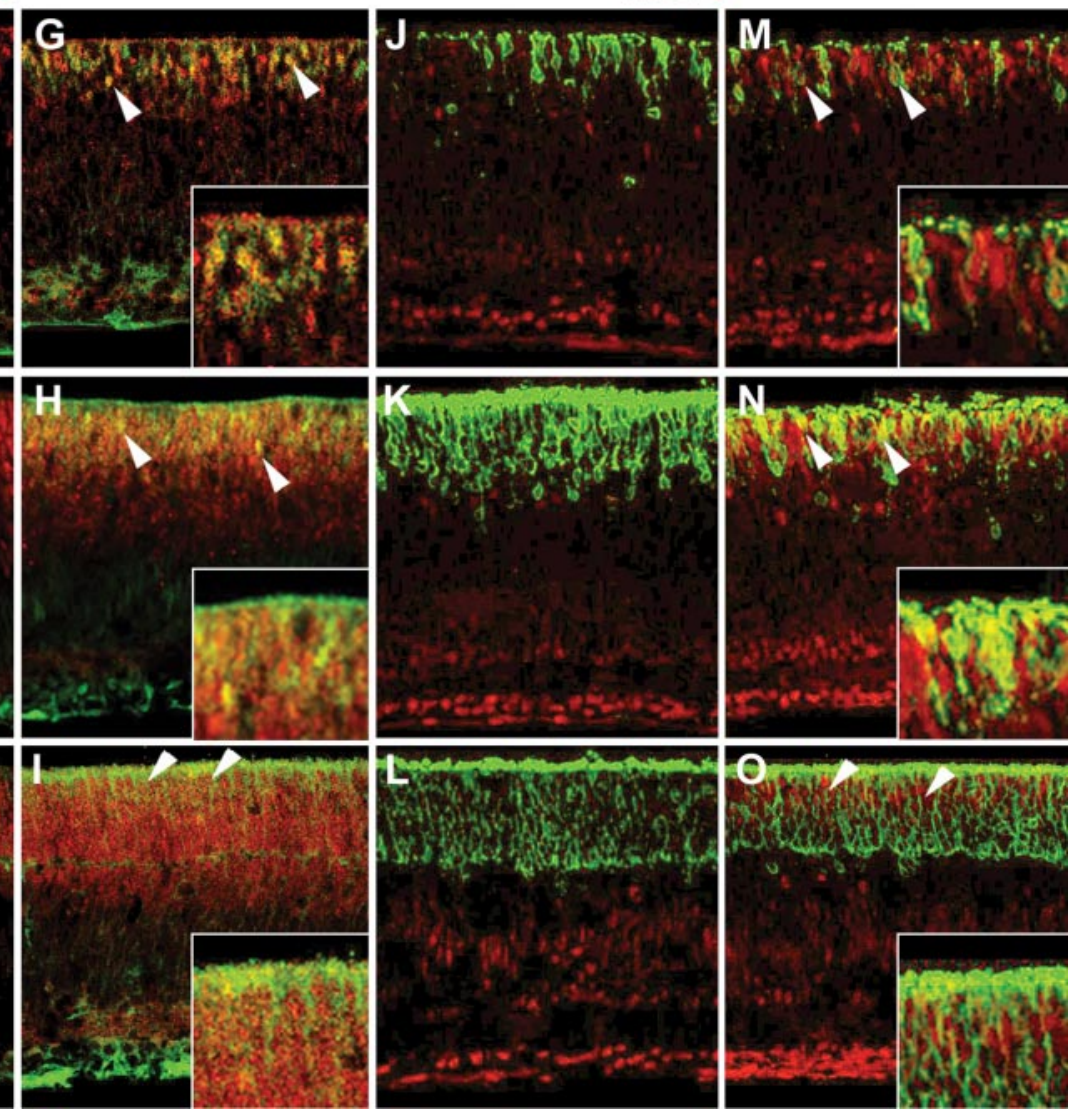

Figure 4. Activation of STAT3 by CNTF in photoreceptor precursors and in differentiating rods. Confocal microscopy images of immunostained postnatal mouse retinal explants without $(A-F, J-L)$ or with $(G-I, M-0) 15$ min exposure to $C N T F(100 \mathrm{ng} / \mathrm{ml})$ are presented. Top, middle, and bottom rows show sections of P1, P3, and P5 retinas, respectively. All panels show merged optical sections of $2 \mu \mathrm{m}$ thickness double stained with two antibodies. Yellow arrows point to cells not costained with the PCNA marker. White arrowheads indicate colocalized staining signals for both antibodies indicated in panels. Scale bar (in $A) A-0,50 \mu \mathrm{m}$. The inserts in $G, H, I, M, N, 0$ show twofold magnification of the ventricular surface regions of the same panels. ac, Amacrine cells; gcl, ganglion cell layer; inl, inner nuclear layer; ipl, inner plexiform layer; onl, outer nuclear layer; vz, ventricular zone. 
A

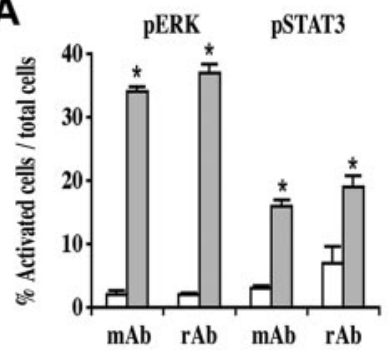

B

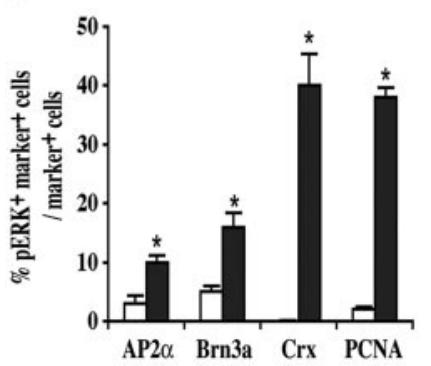

C

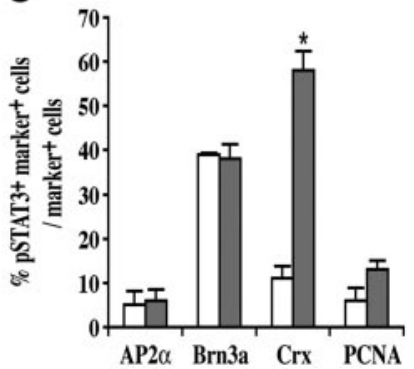

Figure 5. Differential activation of STAT3 and ERK by CNTF in neonatal retina. Quantifications of phospho-ERK and phospho-STAT3 in PO monolayer retinal cells treated with (shaded bars) or without (white bars) CNTF $(100 \mathrm{ng} / \mathrm{ml})$ for 10 min are shown. $A$, Percentages of phospho-ERK (pERK)- or phospho-STAT3 (pSTAT3)-positive cells among total cells as detected by monoclonal ( $\mathrm{mAb} ; n=3$ ) or polyclonal $(\mathrm{rAb} ; n=6)$ antibodies. $B$, Percentages of $\mathrm{pERK} \mathrm{ER}^{+}$ cells within a given cell marker population $(n=3)$. C, Percentages of pSTAT3 ${ }^{+}$cells within a given cell marker population $(n=3)$. In all panels, the asterisks indicate $p$ values $<0.05$ compared with controls not treated with CNTF.

10 min exposure to CNTF caused a 18 -fold increase in the percentage of cells containing phospho-ERK and a three- to fourfold increase in phospho-STAT3-containing cells (Fig. 5A).

We next quantified CNTF-dependent STAT3 and ERK activation in each of the four major cell types at P0, as defined by expression of the AP- $2 \alpha$, Brn3a, Crx, and PCNA markers. Quantification of the progenitor cell marker showed that $78.2 \pm 0.9 \%$ of the cells were $\mathrm{PCNA}^{+}$at $\mathrm{P} 0$. Similar analyses with postmitotic cell markers showed that $15.1 \pm 0.4 \%$ of $\mathrm{P} 0$ retinal cells were AP- $2 \alpha$-expressing amacrine cells, $12.3 \pm 1.3 \%$ were Crxexpressing photoreceptor precursors, and $2.9 \pm 0.1 \%$ of the cells were Brn3a-expressing ganglion cells. A 10 min CNTF treatment resulted in statistically significant ERK activation among all four cell types (Fig. 5B). For example, CNTF induced phospho-ERK in $6 \%$ more $\mathrm{AP}-2 \alpha^{+}$amacrine cells and $10 \%$ more $\mathrm{Brn}^{+} \mathrm{a}^{+}$ganglion cells. CNTF had an even greater effect on the pools of PCNA ${ }^{+}$ progenitor cells and $\mathrm{Crx}^{+}$photoreceptor precursor cells, because both cell types showed a $35 \%$ increase of phospho-ERK ${ }^{+}$cells after CNTF treatment. Moreover, CNTF stimulation caused a significant increase in STAT3 activation among $\mathrm{Crx}^{+}$cells from $11.3 \pm 2.7$ to $57.7 \pm 4.4 \%$ (Fig. $5 C$ ). In contrast, the percentages of cells containing phospho-STAT3 among the AP- $2 \alpha^{+}, \mathrm{Brn}_{3} \mathrm{a}^{+}$, or $\mathrm{PCNA}^{+}$populations were not significantly altered by $\mathrm{CNTF}$ stimulation.

These quantitative analyses of acutely treated monolayer cells confirmed that both proliferating progenitors and postmitotic neurons in the neonatal retina are directly responsive to CNTF stimulation. STAT3 is preferentially activated in the postmitotic photoreceptor precursor cells, whereas ERK is predominantly activated in the proliferative cell population and in $\mathrm{Crx}^{+}$photoreceptor precursor cells.

A

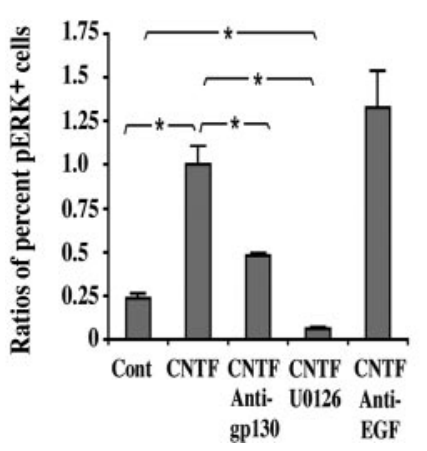

B

Figure 6. Involvement of gp130 in CNTF-induced STAT3 and ERK phosphorylation. Quantifications of phospho-ERK (pERK) and phospho-STAT3 (pSTAT3) in PO monolayer retinal cells treated with or without CNTF ( $10 \mathrm{ng} / \mathrm{ml})$ for $10 \mathrm{~min}$ in the presence or absence of anti-gp130 (1 $\mu \mathrm{g} / \mathrm{ml})$, anti-EGF (10 $\mu \mathrm{g} / \mathrm{ml})$, or the MEK inhibitor U0126 (10 $\mu \mathrm{m})$ are shown. $A$, Ratios of the percentage of $\mathrm{pERK}^{+}$cells among total cells compared with samples treated with CNTF (defined as 1.0$)(n=4)$. B, Ratios of the percentage of $\mathrm{PSTAT}^{+}$cells among total cells compared with samples treated with CNTF (defined as 1.0) $(n=4)$ ). The brackets and asterisks indicate $p$ values $<0.05$ between conditions. Cont, Control.

\section{CNTF-dependent activation of both STAT3 and ERK requires the gp130 receptor and is not mediated through EGF}

In the neonatal retina, exogenous CNTF stimulation induced the phosphorylation of STATs and ERK with similar kinetics, suggesting that activation of both pathways is mediated through the cytokine receptors. To test this hypothesis, we examined whether CNTF-induced STAT and ERK phosphorylation in the retina are affected by blocking reagents for cytokine signaling. P0 retinal monolayer cells were preincubated with a neutralizing antibody for the cytokine receptor gp130 before CNTF stimulation (Park et al., 2003). The presence of gp 130 neutralizing antibody caused a $50 \%$ reduction of CNTF-induced phospho-ERK ${ }^{+}$cells (Fig. $6 A)$. Similarly, the inclusion of anti-gp130 antibodies also led to a $65 \%$ decrease of CNTF-induced phospho-STAT3 ${ }^{+}$cells compared with cells treated with CNTF alone (Fig. $6 B$ ).

In addition to disrupting the gp130 receptor function, we also applied a protein kinase inhibitor, U0126, which specifically blocks activities of the MEK1 and MEK2 kinases that act upstream of the ERK1/2 (Favata et al., 1998). Inclusion of U0126 in dissociated retinal cultures completely abolished endogenous as well as ERK phosphorylation induced by acute exposure to CNTF (Fig. 6A) or EGF (data not shown) but had no effect on CNTFdependent STAT3 phosphorylation (Fig. 6B). Therefore, U0126 interferes with growth-factor-triggered MEK-ERK signaling without affecting CNTF-dependent STAT3 phosphorylation in the retina.

To rule out the possibility that CNTF-induced STAT3 and ERK phosphorylation were attributable to the secondary release of EGF in the retina, we included an EGF neutralizing antibody (Li et al., 1999). At a concentration $(10 \mu \mathrm{g} / \mathrm{ml})$ that was sufficient to inhibit EGF-induced ERK phosphorylation in monolayer retinal cultures (data not shown), the anti-EGF antibody had no effect on CNTF-dependent activation of ERK (Fig. 6A) or STAT3 (Fig. 6B).

Together, these results indicate that CNTF-induced STAT3 and ERK phosphorylation are mediated by the cytokine receptor complex containing gp130. Furthermore, CNTF-triggered ERK phosphorylation requires the upstream kinase MEK and is not caused by the release of EGF from retinal cells stimulated by CNTF. 

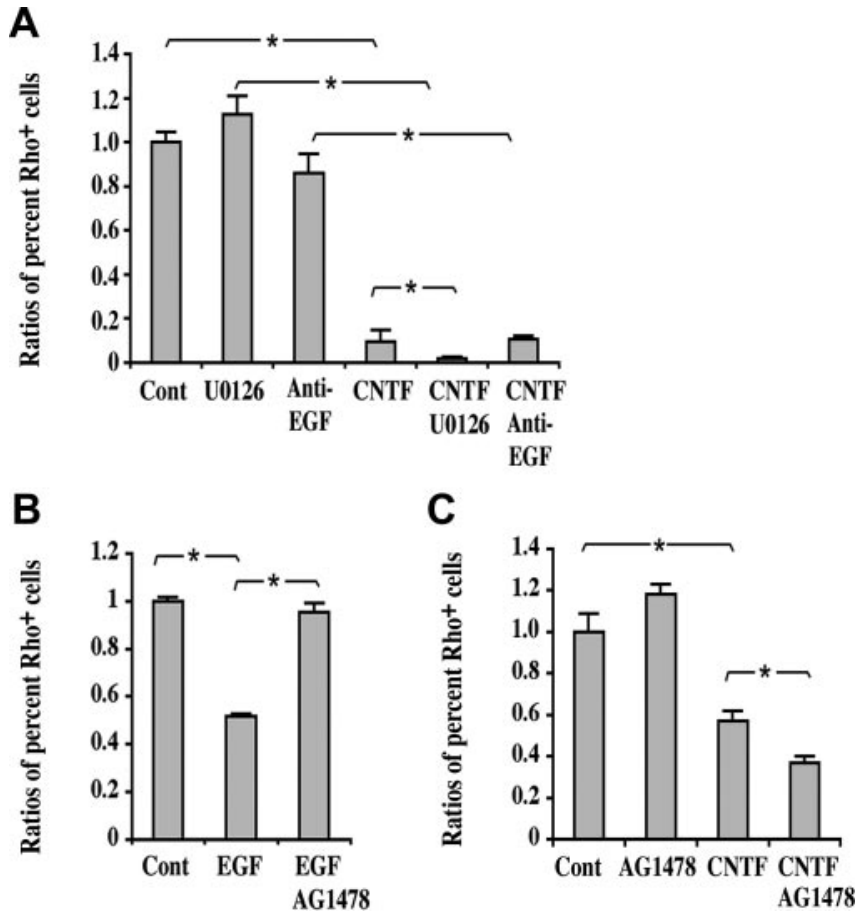

Figure 7. Rod suppression is not mediated by ERK activation and EGFR signaling. Ratios of the percentage of Rho ${ }^{+}$cells among total cells compared with the control (Cont; defined as 1.0) are shown. A, The MEK inhibitor U0126 (10 $\mu \mathrm{M})$ and anti-EGF antibody $(10 \mu \mathrm{g} / \mathrm{ml})$ were added $2 \mathrm{hr}$ before the addition of CNTF ( $100 \mathrm{ng} / \mathrm{ml})$. Retinal explants were cultured from P0 to P6 $(n=6)$. B, The EGFR inhibitor AG1478 ( $300 \mathrm{~nm}$ ) was added at PO and at P3 $2 \mathrm{hr}$ before the addition of EGF. EGF ( $10 \mathrm{ng} / \mathrm{ml}$ ) was added daily to retinal explants cultured from P0 to P6 $(n=4)$. C, The EGFR inhibitor AG1478 ( $300 \mathrm{~nm})$ was added $2 \mathrm{hr}$ before the addition of CNTF $(25 \mathrm{ng} / \mathrm{ml})$ to P1 explants cultured for $5 \mathrm{~d}(n=4)$. The brackets and asterisks indicate $p$ values $<0.05$ between respective conditions.

\section{Suppression of rod photoreceptor differentiation by CNTF requires STAT3 instead of ERK activation}

Because CNTF treatment caused increased phosphorylation of both STAT3 and ERK in $\mathrm{Crx}^{+}$photoreceptor precursors (Fig. $5 B, C)$, we next investigated the potential role of each signaling pathway in regulating rod differentiation. To perturb ERK activation, we used the MEK inhibitor U0126, which effectively blocked CNTF-induced ERK but not STAT phosphorylation (Fig. 6A,B). Consistent with previous reports (Ezzeddine et al., 1997; Schulz-Key et al., 2002), CNTF treatment suppressed Rho ${ }^{+}$ cells to $<10 \%$ of the controls in retinal explants cultured from P1 to P6 (Fig. 7A). Addition of the U0126 inhibitor alone did not affect the differentiation of rod photoreceptors in the explants (Fig. 7A). Moreover, the presence of U0126 did not relieve the suppression of Rho ${ }^{+}$cells by CNTF but instead caused a statistically significant enhancement of this effect (Fig. 7A). These results indicate that the inhibitory effect of CNTF on rod differentiation is not dependent upon ERK activation.

Previous studies have shown that exposure to EGF family of ligands or overexpression of EGFR in the neonatal retina leads to decreased rod photoreceptor production (Lillien, 1995; Neophytou et al., 1997). To test whether cytokine-dependent rod suppression is attributable to potential EGF release triggered by CNTF stimulation, we used an EGF neutralizing antibody (Li et al., 1999). In retinal explants cultured from P1 to P6, addition of the anti-EGF antibody or a control monoclonal antibody, 3C2 (data not shown), did not alter rod production in the presence and absence of exogenous CNTF (Fig. 7A). To rule out the potential involvement of other EGF family ligands that signal through EGFRs, we also used an EGFR-specific inhibitor,
AG1478 (Levitzki and Gazit, 1995; Eguchi et al., 1998), which effectively blocked EGF-induced ERK phosphorylation in monolayer retinal cultures (data not shown). Consistent with previous studies (Lillien, 1995; Neophytou et al., 1997), addition of EGF in P1-P6 retinal explant cultures resulted in up to $50 \%$ suppression of $\mathrm{Rho}^{+}$cells compared with the controls (Fig. 7B). Inclusion of AG1478 completely abolished the rod inhibition caused by exogenous EGF (Fig. 7B), indicating that the EGFRs mediated the EGF effect. In P1-P5 retinal explants, addition of AG1478 alone did not alter the production of $\mathrm{Rho}^{+}$cells compared with the control (Fig. 7C). Instead, AG1478 caused a statistically significant enhancement of rod suppression by CNTF (Fig. 7C), similar to the effect observed for the MEK inhibitor U0126 (Fig. $7 A$ ). Thus, in the presence of exogenous cytokines, blocking either EGFR signaling or ERK phosphorylation appears to potentiate the inhibitory effect of CNTF on rod differentiation.

To selectively disrupt STAT activities, we deployed a phosphotyrosyl peptide that specifically binds to STAT3 and STAT1 to block their dimerization and nuclear translocation (Turkson et al., 2001). In explants cultured either from P1 to P6 or from $\mathrm{P} 2$ to P5, the STAT inhibitor peptide caused a $50 \%$ increase of $\mathrm{Rho}^{+}$cells among total cells in the absence of exogenous CNTF (Fig. 8A). As an alternative means to disrupt STAT protein function, we used a dominant-negative STAT3 mutant (STAT3EE), which contains amino acid residue substitutions in the DNA-binding domain and prevents STAT dimers from activating transcription (Horvath et al., 1995). In P0-P6 retinal explants, cells transfected with STAT3EE showed a 50\% increase of $\mathrm{Rho}^{+}$cells compared with the control in the absence of exogenous cytokine treatment (Fig. $8 \mathrm{~B}$ ). Together, these results indicate that disrupting STAT activity creates a favorable condition for rod photoreceptor differentiation.

Based on these results, we conclude that endogenous cytokines signal through the Jak-STAT instead of the MEK-ERK pathway to negatively regulate rod photoreceptor differentiation in the postnatal retina. Furthermore, the inhibitory effect of CNTF on rod differentiation is not mediated by EGFR signaling.

\section{Discussion}

Our results demonstrate that in the neonatal retina, CNTF elicits distinct phosphorylation patterns of STAT3 and ERK among different cell populations. The newly postmitotic photoreceptor precursors are highly responsive to cytokine signals, but this responsiveness declines as they differentiate. We also show that $\mathrm{CNTF}$ acts via the cytokine receptors to result in STAT3 activation and rod suppression. The effect of cytokine on rod differentiation is not attributable to secondary signals mediated by EGFRs. Moreover, we provide evidence that activation of the Jak-STAT rather than the MEK-ERK signaling pathway is involved in regulating rod photoreceptor differentiation.

The rapid activation of the Jak-STAT and MEK-ERK path- 
A

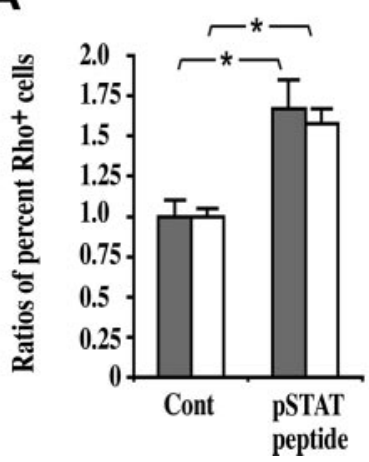

B

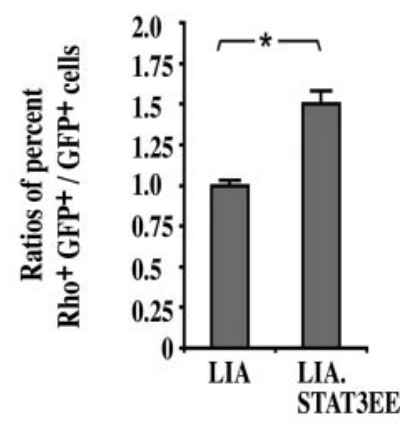

Figure 8. Requirement of STAT3 activation in suppression of rod photoreceptor differentiation. Quantifications of $\mathrm{Rho}^{+}$cells in retinal explants in the absence of exogenous ligands are shown. $A$, Ratios of the percentage of $\mathrm{Rho}^{+}$cells among total cells compared with the controls (Cont; defined as 1.0) in P1-P6 (gray) and P2-P5 (white) explants $(n=5)$. The phosphotyrosyl peptide inhibitor for STAT (pSTAT; $235 \mu \mathrm{m}$ ) was added at the beginning of the cultures. $B$, Ratios of the percentage of Rho ${ }^{+}$and green fluorescent protein-positive $\left(\mathrm{GFP}^{+}\right.$) cells among $\mathrm{GFP}^{+}$ cells compared with the control (defined as 1.0) in transfected P0 explants cultured for $6 \mathrm{~d}$ ( $n=$ 3). A DNA construct expressing enhanced GFP was used to cotransfect with either the control (LIA vector alone) or the STAT3EE (LIA-STAT3EE) constructs. The brackets and asterisks indicate $p$ values $<0.05$ between respective conditions.

ways by CNTF in the postnatal mouse retinal cells strongly supports that CNTF directly triggers these intracellular signaling events through binding to cytokine receptors present on retinal cells. Despite the continuous presence of cytokine signals, CNTFinduced phosphorylation of STAT and ERK is transient in vitro. This is consistent with the existence of feedback regulatory mechanisms in cytokine signal transduction (O'Shea et al., 2002). Two classes of cytokine signal induced cytokine signaling inhibitors, suppressors of cytokine signaling (SOCSs) and protein inhibitors of activated STATs, have been characterized (Shuai, 2000; Yasukawa et al., 2000). Because the activation of both STAT and ERK involves the gp130 receptor, and the decline of phosphoSTATs and phospho-ERK show similar kinetics after CNTF stimulation, it is likely that the observed rapid quenching of cytokine signaling events is mediated by members of the SOCS family of inhibitors, which interfere with cytokine signaling by blocking receptor associated Jak kinases. Further investigations are necessary to determine the precise feedback mechanisms involved in cytokine signal transduction and their potential functions in retinal development.

In the mature rodent retina, the neural protective effects of $\mathrm{CNTF}$ on ganglion cells and photoreceptors are likely mediated by retinal projection neurons and glia, because intravitreal injection of CNTF-like cytokines activates STAT3, ERK, cAMP response element-binding protein, and the immediate early gene c-fos in ganglion cells and Müller cells (Peterson et al., 2000; Wahlin et al., 2000). Our results demonstrate that in the neonatal developing retina, the target cell types for CNTF-like cytokine include both progenitor cells and postmitotic cells. Consistent with expression patterns of cytokine signaling components (Rhee and Yang, 2003; Zhang et al., 2003), postmitotic ganglion cells and amacrine cells contain most of the phospho-STAT3 protein without exogenous ligand treatment. In response to exogenous cytokine stimulation, retinal progenitor cells activate high levels of ERK and relatively low levels of STAT3, whereas the postmitotic neurons including ganglion cells and horizontal cells (data not shown) show further enhanced phosphorylation of STAT and ERK proteins. However, the most striking activation of signal transduction pathways is detected in the postmitotic $\mathrm{Crx}^{+}$pho-

toreceptor precursors, which exhibit a capacity to activate high levels of STAT3 and ERK in response to cytokine stimulation. Our results thus identify progenitor cells, postmitotic neurons, and especially the emerging presumptive photoreceptor cells as targets for cytokine signaling.

In addition to revealing the heterogeneous nature of cytokine signal transduction, our results also show that responses to CNTF-like cytokines are highly dynamic and developmentally regulated. At P0, the majority of retinal progenitor cells are fated to become rod photoreceptors (Young, 1985), and they display three developmental stage-dependent responses to cytokine signals. A proliferating progenitor responds to cytokine signals by activating a high level of phospho-ERK and a low-level of phospho-STAT3. In contrast, a postmitotic $\mathrm{Crx}^{+}$photoreceptor precursor elevates both phospho-STAT3 and phospho-ERK when encountering cytokine signals. $\mathrm{A} \mathrm{Crx}^{+}$presumptive photoreceptor retains its cytokine responsiveness when it begins to synthesize rhodopsin and subsequently loses its response to cytokine stimuli as it further matures. These observations are consistent with previous findings that CNTF can assert its influence on photoreceptor differentiation even after the progenitor cells have exited from the cell cycle, and that high levels of rhodopsin expression are closely correlated with the resistance of a presumptive rod photoreceptor cell to CNTF inhibition (Ezzeddine et al., 1997; Neophytou et al., 1997; Schulz-Key et al., 2002). The developmental stage-dependent responses of retinal cells to cellextrinsic cytokine signals are likely dictated by cell-intrinsic changes as found in the developing cortex (Viti et al., 2003). Currently, the cell-intrinsic properties that determine either the responsiveness toward cytokine signals or the specificity of intracellular signaling events have not been characterized in the developing retina.

The differential activation of STAT3 and ERK in the postnatal retina suggests that these signaling molecules play distinct roles during retinogenesis. In LIFR $\beta$ - or CNTFR $\alpha$-deficient retinal explants, rod photoreceptor cells are increased (Ezzeddine et al., 1997), indicating that endogenous cytokine signaling mediated by either activated STAT or ERK plays a role in suppressing rod photoreceptor differentiation. Our signaling pathway perturbation experiments using the highly specific MEK inhibitor U0126 demonstrate that MEK-mediated ERK activation is not involved in cytokine-mediated suppression of rod differentiation. In contrast, blocking phospho-STAT activities by either the phosphotyrosyl peptide inhibitor or a dominant-negative STAT3 enhances rod photoreceptor differentiation in vitro. Because these results were obtained in the absence of exogenous cytokines, they strongly support a role for endogenous STAT3 activation in negative regulation of photoreceptor differentiation in the postnatal retina (Zhang et al., 2004). Ozawa et al. (2004) showed recently that abolishing STAT3 activity in the embryonic retina results in precocious expression of the homeobox gene Crx, which is required for terminal differentiation of rod and cone photoreceptors (Furukawa et al., 1999). However, upregulation of Crx mRNA does not seem to correlate with an earlier onset of photoreceptor differentiation (Ozawa et al., 2004). This may either reflect the cumulative effects of STAT3 deficiency during retinogenesis or compensation of STAT3 function by other STATs. Our results clearly show that proliferating progenitors and postmitotic retinal cells including $\mathrm{Crx}^{+}$photoreceptor precursors respond directly albeit distinctly to CNTF signals. It remains to be determined whether STAT3 function is required at multiple stages of photoreceptor development. Intriguingly, we have observed that attenuation of CNTF-induced ERK activation leads to 
potentiation of the biological effect mediated by STAT (Fig. 7A), suggesting that the ERK and STAT pathways share common downstream effectors in the retina.

During neural development, distinct classes of signaling molecules may simultaneously influence various aspects of cell behavior. EGFR-mediated EGF signals, in addition to CNTF and LIF, have been shown to modulate postnatal retinogenesis by suppressing rod photoreceptors (Lillien, 1995; Neophytou et al., 1997). The similar biological effects of EGF and CNTF family of ligands in the postnatal developing retina raise the question of whether influence of CNTF may be in part mediated by the secondary release of EGF family of ligands that signal through EGFRs. We demonstrate here that in the neonatal retina, the cytokine receptor gp130 directly mediates cytokine-dependent activation of both STAT and ERK, and that the activation of ERK by cytokines is mediated by its upstream kinase, MEK1/2. Thus, phosphorylation of the cytokine $\beta$ receptors is likely to provide docking sites for intracellular signaling components that diverge cytokine signals to the MEK-ERK signaling cascade in the developing retina. Furthermore, using EGF neutralizing antibodies and the EGFR-specific inhibitor, we have ruled out the possibility that CNTF-triggered signaling events and their subsequent influence on rod differentiation are mediated through EGFRs.

Our current study reveals the complex and dynamic intracellular signaling events in the developing retina. Based on our findings and previous studies, we propose that STAT and/or ERK activation induced by ambient endogenous signaling molecules plays different roles in progenitor cells and postmitotic cells. Elevated STAT and/or ERK phosphorylation may influence cell fate specification of uncommitted progenitors but regulate neuronal differentiation and survival in postmitotic cells. In the postnatal retina, cytokine-induced STAT activation controls photoreceptor cell differentiation by suppressing precocious rhodopsin expression. As a consequence of STAT activation, nascent photoreceptor cells may accumulate cytokine signaling inhibitors and thus become resistant to environmental cytokine as well as other STAT-activating signals to reach maturation and sustain their physiological function. Concomitantly, postmitotic Müller glia may require cytokine and other growth factor signaling to further differentiate and form the glial scaffold necessary for retinal structure and maintenance (Lillien, 1995; Lillien and Wancio, 1998; Goureau et al., 2004). The integration of intracellular signaling events triggered by various cell-extrinsic cues in progenitor cells and postmitotic cells may thus contribute to a balanced production of postnatal cell types and their proper differentiation.

\section{References}

Altshuler D, Cepko C (1992) A temporally regulated, diffusible activity is required for rod photoreceptor development in vitro. Development 114:947-957.

Bao ZZ, Cepko CL (1997) The expression and function of Notch pathway genes in the developing rat eye. J Neurosci 17:1425-1434.

Bhattacharya S, Dooley C, Soto F, Madson J, Das AV, Ahmad I (2004) Involvement of Ath3 in CNTF-mediated differentiation of the late retinal progenitors. Mol Cell Neurosci 27:32-43.

Bonni A, Frank DA, Schindler C, Greenberg ME (1993) Characterization of a pathway for ciliary neurotrophic factor signaling to the nucleus. Science 262:1575-1579.

Boulton TG, Stahl N, Yancopoulos GD (1994) Ciliary neurotrophic factor/ leukemia inhibitory factor/interleukin 6/oncostatin M family of cytokines induces tyrosine phosphorylation of a common set of proteins overlapping those induced by other cytokines and growth factors. J Biol Chem 269:11648-11655.

Cayouette M, Barres BA, Raff M (2003) Importance of intrinsic mecha- nisms in cell fate decisions in the developing rat retina. Neuron 40:897-904.

Cepko CL, Austin CP, Yang XJ, Alexiades M, Ezzeddine D (1996) Cell fate determination in the vertebrate retina. Proc Natl Acad Sci USA 93:589-595.

Chen S, Wang QL, Nie Z, Sun H, Lennon G, Copeland NG, Gilbert DJ, Jenkins NA, Zack DJ (1997) Crx, a novel Otx-like paired-homeodomain protein, binds to and transactivates photoreceptor cell-specific genes. Neuron 19:1017-1030.

Davis S, Aldrich TH, Stahl N, Pan L, Taga T, Kishimoto T, Ip NY, Yancopoulos GD (1993) LIFR beta and gp130 as heterodimerizing signal transducers of the tripartite CNTF receptor. Science 260:1805-1808.

Eguchi S, Numaguchi K, Iwasaki H, Matsumoto T, Yamakawa T, Utsunomiya H, Motley ED, Kawakatsu H, Owada KM, Hirata Y, Marumo F, Inagami T (1998) Calcium-dependent epidermal growth factor receptor transactivation mediates the angiotensin II-induced mitogen-activated protein kinase activation in vascular smooth muscle cells. J Biol Chem 273:8890-8896.

Ezzeddine ZD, Yang XJ, DeChiara T, Yancopoulos G, Cepko CL (1997) Postmitotic cells fated to become rod photoreceptors can be respecified by CNTF treatment of the retina. Development 124:1055-1067.

Favata MF, Horiuchi KY, Manos EJ, Daulerio AJ, Stradley DA, Feeser WS, Van Dyk DE, Pitts WJ, Earl RA, Hobbs F, Copeland RA, Magolda RL, Scherle PA, Trzaskos JM (1998) Identification of a novel inhibitor of mitogen-activated protein kinase kinase. J Biol Chem 273:18623-18632.

Fuhrmann S, Kirsch M, Hofmann HD (1995) Ciliary neurotrophic factor promotes chick photoreceptor development in vitro. Development 121:2695-2706.

Furukawa T, Morrow EM, Cepko CL (1997) Crx, a novel otx-like homeobox gene, shows photoreceptor-specific expression and regulates photoreceptor differentiation. Cell 91:531-541.

Furukawa T, Morrow EM, Li T, Davis FC, Cepko CL (1999) Retinopathy and attenuated circadian entrainment in Crx-deficient mice. Nat Genet 23:466-470.

Goureau O, Rhee KD, Yang XJ (2004) Ciliary neurotrophic factor promotes Müller glia differentiation from the postnatal retinal progenitor pool. Dev Neurosci, in press.

Heinrich PC, Behrmann I, Muller-Newen G, Schaper F, Graeve L (1998) Interleukin-6-type cytokine signalling through the gp130/Jak/STAT pathway. Biochem J 334:297-314.

Holt CE, Bertsch TW, Ellis HM, Harris WA (1988) Cellular determination in the Xenopus retina is independent of lineage and birth date. Neuron $1: 15-26$.

Horvath CM, Wen Z, Darnell Jr JE (1995) A STAT protein domain that determines DNA sequence recognition suggests a novel DNA-binding domain. Genes Dev 9:984-994.

Ip NY, McClain J, Barrezueta NX, Aldrich TH, Pan L, Li Y, Wiegand SJ, Friedman B, Davis S, Yancopoulos GD (1993) The alpha component of the CNTF receptor is required for signaling and defines potential CNTF targets in the adult and during development. Neuron 10:89-102.

Kirsch M, Fuhrmann S, Wiese A, Hofmann HD (1996) CNTF exerts opposite effects on in vitro development of rat and chick photoreceptors. NeuroReport 7:697-700.

Laird DW, Molday RS (1988) Evidence against the role of rhodopsin in rod outer segment binding to RPE cells. Invest Ophthalmol Vis Sci 29:419-428.

La Spada AR, Fu YH, Sopher BL, Libby RT, Wang X, Li LY, Einum DD, Huang J, Possin DE, Smith AC, Martinez RA, Koszdin KL, Treuting PM, Ware CB, Hurley JB, Ptacek LJ, Chen S (2001) Polyglutamine-expanded ataxin-7 antagonizes CRX function and induces cone-rod dystrophy in a mouse model of SCA7. Neuron 31:913-927.

Levitzki A, Gazit A (1995) Tyrosine kinase inhibition: an approach to drug development. Science 267:1782-1788.

Li J, Lin ML, Wiepz GJ, Guadarrama AG, Bertics PJ (1999) Integrinmediated migration of murine B82L fibroblasts is dependent on the expression of an intact epidermal growth factor receptor. J Biol Chem 274:11209-11219.

Lillien L (1995) Changes in retinal cell fate induced by overexpression of EGF receptor. Nature 377:158-162.

Lillien L (1998) Progenitor cells: what do they know and when do they know it? Curr Biol 8:R872-R874.

Lillien L, Wancio D (1998) Changes in epidermal growth factor receptor 
expression and competence to generate glia regulate timing and choice of differentiation in the retina. Mol Cell Neurosci 10:296-308.

Liu W, Khare SL, Liang X, Peters MA, Liu X, Cepko CL, Xiang M (2000) All $\mathrm{Brn} 3$ genes can promote retinal ganglion cell differentiation in the chick. Development 127:3237-3247.

Livesey FJ, Cepko CL (2001) Vertebrate neural cell-fate determination: lessons from the retina. Nat Rev Neurosci 2:109-118.

Matsuda T, Cepko CL (2004) Electroporation and RNA interference in the rodent retina in vivo and in vitro. Proc Natl Acad Sci USA 101:16-22.

Neophytou C, Vernallis AB, Smith A, Raff MC (1997) Muller-cell-derived leukaemia inhibitory factor arrests rod photoreceptor differentiation at a postmitotic pre-rod stage of development. Development 124:2345-2354.

Oh H, Fujio Y, Kunisada K, Hirota H, Matsui H, Kishimoto T, YamauchiTakihara K (1998) Activation of phosphatidylinositol 3-kinase through glycoprotein 130 induces protein kinase B and p70 S6 kinase phosphorylation in cardiac myocytes. J Biol Chem 273:9703-9710.

O'Shea JJ, Gadina M, Schreiber RD (2002) Cytokine signaling in 2002: new surprises in the Jak/Stat pathway. Cell 109 [Suppl]:S121-S131.

Ozawa Y, Nakao K, Shimazaki T, Takeda J, Akira S, Ishihara K, Hirano T, Oguchi Y, Okano H (2004) Downregulation of STAT3 activation is required for presumptive rod photoreceptor cells to differentiate in the postnatal retina. Mol Cell Neurosci 26:258-270.

Park JI, Strock CJ, Ball DW, Nelkin BD (2003) The Ras/Raf/MEK/extracellular signal-regulated kinase pathway induces autocrine-paracrine growth inhibition via the leukemia inhibitory factor/JAK/STAT pathway. Mol Cell Biol 23:543-554.

Peterson WM, Wang Q, Tzekova R, Wiegand SJ (2000) Ciliary neurotrophic factor and stress stimuli activate the Jak-STAT pathway in retinal neurons and glia. J Neurosci 20:4081-4090.

Rajan P, Symes AJ, Fink JS (1996) STAT proteins are activated by ciliary neurotrophic factor in cells of central nervous system origin. J Neurosci Res 43:403-411.

Rhee KD, Yang XJ (2003) Expression of cytokine signal transduction components in the postnatal mouse retina. Mol Vis 9:715-722.

Schulz-Key S, Hofmann HD, Beisenherz-Huss C, Barbisch C, Kirsch M (2002) Ciliary neurotrophic factor as a transient negative regulator of rod development in rat retina. Invest Ophthalmol Vis Sci 43:3099-3108.

Shuai K (2000) Modulation of STAT signaling by STAT-interacting proteins. Oncogene 19:2638-2644.

Stahl N, Yancopoulos GD (1994) The tripartite CNTF receptor complex: activation and signaling involves components shared with other cytokines. J Neurobiol 25:1454-1466.

Turkson J, Ryan D, Kim JS, Zhang Y, Chen Z, Haura E, Laudano A, Sebti S, Hamilton AD, Jove R (2001) Phosphotyrosyl peptides block Stat3mediated DNA binding activity, gene regulation, and cell transformation. J Biol Chem 276:45443-45455.

Turner DL, Cepko CL (1987) A common progenitor for neurons and glia persists in rat retina late in development. Nature 328:131-136.

Turner DL, Snyder EY, Cepko CL (1990) Lineage-independent determination of cell type in the embryonic mouse retina. Neuron 4:833-845.

Viti J, Feathers A, Phillips J, Lillien L (2003) Epidermal growth factor receptors control competence to interpret leukemia inhibitory factor as an astrocyte inducer in developing cortex. J Neurosci 23:3385-3393.

Wahlin KJ, Campochiaro PA, Zack DJ, Adler R (2000) Neurotrophic factors cause activation of intracellular signaling pathways in Muller cells and other cells of the inner retina, but not photoreceptors. Invest Ophthalmol Vis Sci 41:927-936.

West-Mays JA, Zhang J, Nottoli T, Hagopian-Donaldson S, Libby D, Strissel KJ, Williams T (1999) AP-2alpha transcription factor is required for early morphogenesis of the lens vesicle. Dev Biol 206:46-62.

Wetts R, Fraser SE (1988) Multipotent precursors can give rise to all major cell types of the frog retina. Science 239:1142-1145.

Xie HQ, Adler R (2000) Green cone opsin and rhodopsin regulation by CNTF and staurosporine in cultured chick photoreceptors. Invest Ophthalmol Vis Sci 41:4317-4323.

Yang XJ (2004) Roles of cell-extrinsic growth factors in vertebrate eye pattern formation and retinogenesis. Semin Cell Dev Biol 15:91-103.

Yasukawa H, Sasaki A, Yoshimura A (2000) Negative regulation of cytokine signaling pathways. Annu Rev Immunol 18:143-164.

Young RW (1985) Cell differentiation in the retina of the mouse. Anat Rec 212:199-205.

Zhang SS, Wei JY, Li C, Barnstable CJ, Fu XY (2003) Expression and activation of STAT proteins during mouse retina development. Exp Eye Res 76:421-431.

Zhang SS, Wei J, Qin H, Zhang L, Xie B, Hui P, Deisseroth A, Barnstable CJ, Fu XY (2004) STAT3-mediated signaling in the determination of rod photoreceptor cell fate in mouse retina. Invest Ophthalmol Vis Sci 45:2407-2412.

Zhang XM, Yang XJ (2001) Regulation of retinal ganglion cell production by Sonic hedgehog. Development 128:943-957. 